\title{
Emotional Intelligence and Immigrant Entrepreneurship Development: A Correlation Analysis of the Lebanese Family Entrepreneurships in Nigeria
}

\author{
Kenneth Chukwujioke Agbim ${ }^{1}$ \\ ${ }^{1}$ Business Administration Department, University of Agriculture, Makurdi, Nigeria \\ Correspondence: Kenneth Chukwujioke Agbim, Business Administration Department, University of Agriculture, \\ Makurdi, Nigeria, E-mail: kennethagbim2012@gmail.com
}

Received: June 5, 2018

Accepted: June 14, 2018

Online Published: July 23, 2018

\begin{abstract}
The arrival of the first Lebanese immigrant in Lagos in 1890 has been followed by increase in the number of Lebanese immigrants in Nigeria. The immigrants get attached to their families on arrival. This is owing to the instrumental, financial, psychological and emotional supports they receive from their families to enable them assimilate into the Nigerian community. In spite of their contributions to the economic and infrastructural development of Nigeria through the family-owned immigrant entrepreneurships they have developed, no study seems to have been conducted in this area. Consequently, based on data from selected Lebanese family-owned entrepreneurships, this study examines the relationship between emotional intelligence and immigrant entrepreneurship development. The study adopted mail questionnaire survey design. The generated data through questionnaire were analyzed using Pearson's correlation. It was found that emotional intelligence is significantly related to the dimensions of immigrant entrepreneurship development, that is, entrepreneurial intention, entrepreneurial capabilities, entrepreneurial networking and entrepreneurial success. Based on the results, the study recommends exposing new immigrants and immigrant entrepreneurs to trainings and programs that will improve their emotional intelligence, entrepreneurial behaviour, capabilities, networking attitude and success mindset. The ultimate effect of these trainings and programs is increase in the development of immigrant entrepreneurships.
\end{abstract}

Keywords: Emotional intelligence, Entrepreneurship development, Immigrant entrepreneurship development, Entrepreneurial intention, Entrepreneurial capabilities, Entrepreneurial networking, Entrepreneurial success.

\section{Introduction}

The term "Emotional Intelligent" (EI) is made up two words - emotion and intelligence. Cabanac (2002) define emotion as any mental experience with high intensity and high hedonic content (pleasure/displeasure). Salovey and Mayer (1990) opine that intelligence involves the ability to carry out abstract reasoning. EI as a concept was first introduced into the scientific psychological literature by Salovey and Mayer based on Gardner's theory of multiple intelligences. Gardner notes that one of the seven intelligences possessed by humans is personal 
intelligence - intrapersonal intelligence and interpersonal intelligence. Intrapersonal intelligence pertains to ability to know and access one's feeling about life, range of emotions, distinguish between emotions and to rely on them as means of guiding one's behaviour. Interpersonal intelligence refers to one's ability to work with others by accurately interpreting their emotions and using one's own emotion to relate them effectively (Gardner, 1983; Salovey \& Mayer, 1990; Wong et al., 2007).

Extant literature on EI and entrepreneurship has shown that there are somewhat few empirical researches that have assessed the role of EI in promoting entrepreneurship. Specifically, EI has been related to entrepreneurship development (Rhee \& White, 2007), performance (McLaughlin, 2012) and entrepreneurial intention (Greenberg \& Baron, 2008). Since EI is a predictor of entrepreneurial intention and entrepreneurial behaviour, individuals are adjusting their emotions as well as others' emotion based on the prevailing situations so as to influence and create in others an entrepreneurial intention (Zampetakis et al., 2009). Individuals with high EI tend to get involved in entrepreneurial activities (Nikolaou \& Tsaousis, 2002). This is because EI help individuals to manage their job stress, challenges associated with business start-up and to transfer all unnecessary feelings into motivational factors (Zampetakis et al., 2009).

Entrepreneurs carry out their intention by networking to gain experience, exploit opportunities, create and grow their enterprises and improve the performance of the enterprises (Siqueira, 2007; Bagwell, 2008; Kariv et al., 2009; Collins \& Low, 2010; Ensign \& Robinson, 2011; Paoloni et al., 2017). EI improves an entrepreneur's talent, capability and social effectiveness (Goleman, 1995; Khatoon, 2013). The integration of explicit knowledge and tacit emotional abilities leads to greater entrepreneurial success (Zeidner et al., 2009). EI plays an important role in determining a person's ability to succeed. Wong and Law (2002) argue that individuals, who recognize their emotions and that of others, possess the skills and capabilities to improve their performance and to achieve better success. Individuals with higher than average EI are more successful in meeting environmental demands and pressures. Conversely, a deficiency in EI can mean a lack of success (Bar-On, 1997). People are sometimes successful not because of their knowledge of the tasks, but due to their ability to manage people socially and emotionally; this ability is embodied in EI.

One type of entrepreneurship that is being encouraged by various governments is immigrant entrepreneurship. Chrysostome and Lin (2010) assert that immigrant entrepreneurship contributes to job and wealth creation for the host country. Other contributions as stated by Oliveira (2008) are economic growth, changing the urban landscape, revitalizing the local markets and even creating new ones such as ethnic tourism, supplying new products and services at competitive prices, creating employment opportunities, combating social exclusion, and improving the living standards of the disadvantaged groups. Moreover, owing to the involvement of immigrant entrepreneurs in self-employment and the high rate of immigrant entrepreneurship in countries that facilitate the immigration of would-be entrepreneurs, many countries are now designing and implementing programs geared towards attracting immigrant entrepreneurs. These programs include special visas and less stringent entry requirements.

One group of immigrant entrepreneurs whose contributions to the development of Nigeria cannot be overlooked is the Lebanese. Plamodon (2004) states that the educated and talented Lebanese population is well known for their marketing prowess so much so that Lebanon at one time became a commercial center for the entire Middle East (Pistrui et al., 2008). The immigration of the Lebanese to Nigeria, the creation and further development of Lebanese immigrant entrepreneurship started with the arrival of the first Lebanese immigrant, Elias Khoury in Lagos in 1890. The Lebanese immigrant entrepreneurships increased in number following the arrival of more Lebanese families and the formation of the Lebanese community and networks in Nigeria (Adebayo, 2003, n.d.). These networks provided information to help immigrants reduce uncertainty and mitigate risks and thereby help 
them overcome traditional barriers associated with immigration (Leblang et al., 2006). The networks supports the immigrants emotionally, financially, psychologically (through their social community), and instrumentally by assisting the immigrants to assimilate into the Nigerian community.

The family is the main refuge for members of the Lebanese society. Indeed, Lebanese turn first to their families for assistance in almost every aspect of their lives, including migration (Joseph, 2006). Through these emotionally driven networks, the Lebanese immigrants in Nigeria have donated funds to churches, mosques, constructed roads, renovated rural schools and health facilities, improved cemeteries, developed orphanages and rest homes for the elderly, provided scholarship for indigent students and made donations to victims of natural and man-made disasters in different parts of Nigeria (Adebayo, n.d.). In spite of the contributions of EI to entrepreneurship and the laudable achievements of the Lebanese family-owned entrepreneurships in Nigeria, no study seems to have related EI to immigrant entrepreneurship among the Lebanese. This is the gap this study seeks to fill. The study is significant as the findings will motivate the Lebanese community in Nigeria to develop more immigrant entrepreneurships. The outcome of the study will further spur the government to create a better enabling business environment for more immigrants to develop family-owned entrepreneurships.

\section{Emotional Intelligence}

EI is the ability to identify, assess and control the emotions of oneself, of others and of groups (Harms \& Credé, 2010). Goleman (2001:2) define EI as "the ability to recognize and regulate emotions in ourselves and others". EI focuses on the ability to know your own emotions and manage them, as well as ability to detect emotional cues and how to react accordingly (Fakhreldin \& Hattab, 2015). Bar-On (1997) notes that through training, programming and therapy, EI can be developed and improved over time. Some definitions of EI have been categorized into ability, trait and mixed models.

EI ability model (or cognitive emotional ability) was developed by Mayer and Salovey. This model assesses individual differences in the interface of emotion (mood manipulation, emotion regulation) with cognitive processes (such as memory, judgment and behaviour). It regards EI as a pure form of mental ability and thus as a pure intelligence. The model has four branches - emotional perception, emotional assimilation, emotional understanding and emotion management (Mayer \& Salovey, 1997; Mayer et al., 2002). EI trait model (or emotional self-efficacy) was developed by Petrides and Furnham. It assesses individual differences in emotion-related dispositions. Emotional self-efficacy incorporates abilities within a more general framework of individual self-perceived emotionality and emotional self-efficacy (Petrides \& Furnham, 2001).

The mixed model was initiated by Reuven Bar-On and then elaborated by Daniel Goleman (Goleman, 2001; Caruso et al., 2002; Aslan \& Erkuş, 2008). It focuses on mental abilities, existence and properties (Aslan \& Erkuş, 2008). Reuven Bar-On, in his model perceives EI as a collection of cognitive ability and a personality trait. The model is categorized as intra-personal (self-regard, emotional self-awareness, assertiveness, independence, self-actualization), interpersonal (empathy, social responsibility, interpersonal relationship), adaptability (reality testing, flexibility, problem solving), stress management (stress tolerance, impulse control), and general mood (optimism, happiness) (Bar-On, 1997). Like Reuven Bar-On's model, the model developed by Daniel Goleman integrates cognitive ability and personality traits. It was initially made up of five domains (knowing your emotions, managing your own emotions, motivating yourself, recognizing and understanding other people's emotions and managing relationships) (Goleman, 1995).

Based on the statistical analysis performed by Richard Boyatzis, Goleman afterwards, reduced the domain of the model to four, while the competencies were reduced from 25 to 18. The four domains are self-awareness, self-management, social awareness and social skills (Goleman, 2001; Bradberry \& Greaves, 2009, as cited in Danquah, 2015). Mixed model differ from ability-based model (Mayer et al., 2004) because the former combine 
emotions, motivational factors, assertiveness, flexibility, need for achievement and personality traits (such as warmth, outgoingness, optimism, and persistence) in their definitions (Bar-On, 1997; Cote et al., 2010). In spite of the criticisms against Daniel Goleman's model, it remains the most accepted owing to the support accorded it by the works of Boyatzis et al. (1998) and Mayer et al. (2001). Moreover, despite the differences in the models, each of them has a relationship with other related constructs like entrepreneurship (Rhee \& White, 2007).

- Self-Awareness: concerns knowing one's internal states, preferences, resources and intuitions. Self-awareness involves emotional awareness, which is deemed as the fundamental core ability of emotional intelligence, and ability to know one's strength, limits and self-confidence.

- Self-Management: refers to managing ones' internal states, impulses and resources. The self-management cluster contains six competencies, including self-control, being trustworthy, conscientious, and adaptable, taking initiative and having a drive to achieve.

- Social Awareness: refers to how people handle relationships and awareness of others' feelings, needs and concerns. It involves empathy, a service orientation toward customers or clients, political awareness and understanding others as well as ability to cultivate opportunities through different kinds of people.

- Social Skills: concerns the skill or adeptness at inducing desirable responses in others, including general communication ability, ability to influence others, manage conflict, inspire others via a vision, recognize and catalyze change, collaborate with others, and promote teamwork.

\section{Immigrant Entrepreneurship Development}

Immigrants are people from another country but who reside in a certain host country. These immigrant entrepreneurs establish immigrant entrepreneurships in the host country to achieve independence and fulfillment or to avoid (or escape) unemployment (Dalhammar, 2004). Immigrant entrepreneur is also defined as any newly immigrated person who establishes a business in the host country to sustain himself or herself (Tengeh \& Nkem, 2017). Aaltonen and Akola (2014) asserts that an immigrant entrepreneur or immigrant business owner is a person who has immigrated to a new country and started a business there. Vinogradov and Isaksen (2008) describe an immigrant entrepreneur as a person who arrives in the country and starts a business for the purpose of economic survival. It can be deduced from these definitions that an immigrant entrepreneur is a foreign born business owner, who has foreign origin, and is involved in economic innovation, organization creation and profit-seeking in the market sector (Kahn et al., 2013) of the host country.

Immigrant entrepreneurs can be necessity or opportunity entrepreneurs depending on whether they were driven into entrepreneurship by push or pull factors. Williams (2008) notes that necessity entrepreneurs are driven into entrepreneurship by push factors because other options for work are absent or unsatisfactory whereas opportunity entrepreneurs are driven into entrepreneurship by pull factors mostly out of choice. Slavnic (2004) argue that there are some necessity entrepreneurs who were pushed into entrepreneurship just to seek more freedom and independence. These sets of entrepreneurs are usually driven by opportunity factors. They include immigrants who moved to the host country to start-up an enterprise based on identified opportunities, those who moved as students but started an enterprise after their studies, and those who came to seek job opportunities but later started their own enterprise when they failed to secure a paid job (Chrysostome, 2010). When looking for jobs in the host country, immigrants face challenges such as lack of sufficient language skills, discrimination, incompatible education and training (Omar, 2011), racial, religious and cultural differences (Ensign \& Robinson, 2011).

Dalhammar (2004) define immigrant entrepreneurship as the process by which an immigrant establishes a business in a host country (or country of settlement) which is not the immigrant's country of origin. In addition, immigrant entrepreneurship is described as business activities, which are conducted by immigrants in their host 
countries either with the assistance of social networks or through individual initiative (Tengeh et al., 2011). Entrepreneurship development is the process of actualizing an innovative intention by an individual or group of individuals in either a new or old enterprise through networking to acquire the requisite capabilities that will enhance the success of the venture in the face of environmental uncertainties (Agbim \& Oriarewo, 2012; Agbim et al., 2013). Based on this definition, entrepreneurship development has four dimensions - entrepreneurial intention, entrepreneurial networking, entrepreneurial capabilities and entrepreneurial success. These dimensions also apply in immigrant entrepreneurship development.

- Entrepreneurial Intention

Entrepreneurial intention is a conscious state of mind that directs attention (and therefore experience and action) toward a specific object (goal) or pathway to achieve it (Bird, 1989). It is the commitment to start a new business (Krueger et al., 2000). Intentions influence behaviour (Ajzen, 1991) and predict entrepreneurial action (Krueger et al., 2000). The intention to behave in a certain way depends on the person's attitude towards that behaviour. Attitude can increase or decrease the level of intention to engage in any activity (Ajzen, 1991). Research has shown that EI is one of the factors that influence entrepreneurial intention (Greenberg \& Baron, 2008). Thus, for the purpose of this study, entrepreneurial intention is defined as the expression of the willingness and deliberate plan to start-up a business. A person's intention to become an entrepreneur directs the person's attention to network for the needed resources to establish the business.

\section{- Entrepreneurial Networking}

Entrepreneurial networking is the process whereby a protégé (budding, nascent or even an established entrepreneur) strategically (or non-strategically) and formally (or informally) connects and maintains interactive and interdependent relationships with business experts and/or the business stakeholders through online or offline (face-to-face) contacts for the purpose of acquiring, sharing or exchanging entrepreneurial resources. Thus, entrepreneurial networking can be strategic, non-strategic, online and offline. Strategic networking is the process of connecting and cooperating with other entrepreneurs and/or business stakeholders based on adopted business strategy. When the essence of connecting and cooperating with other entrepreneurs and/or business stakeholders is not based on a specific business strategy it is called non-strategic networking. Entrepreneurial networking is formal when it is intentionally planned before it is started and informal when it is started unintentionally without planning. Online networking is the process of connecting and cooperating with other entrepreneurs and/or business stakeholders through advanced virtual and real-time information and communication technology and/or internet based platforms. The process of connecting and cooperating with other entrepreneurs and/or business stakeholders through face-to-face forum is called offline networking.

Cheuk (2007) opines that research has emphasized the importance of networking through face-to-face and the new media. This is evident from the recent researches that have related networking through the new media among entrepreneurs (Slotte-Kock \& Coviello, 2010) to the EI. Extraversion, emotional stability and openness to experience have been related to uses of social applications on the internet (Forret \& Dougherty, 2001; Correa et al., 2010; Wolff \& Kim, 2012). Personality dimensions (i.e., extraversion, agreeableness, openness to experience) have been related to networking behaviour (Muscanell \& Guadagno, 2012; Wolff \& Kim, 2012). It follows that EI is increasingly becoming significant in networking (Correa et al., 2010). Therefore, networking is a must-do activity for entrepreneurs as professional contacts link entrepreneurs with critical opportunities, support and resources (Torres-Coronas et al., 2015).

This goes further to show that the use of the new media such as Facebook is enhancing the importance of such networks as professional, social, business and ethnic networks in business. O'Donnell (2004) note that networking can be positioned along a continuum from "reactive" to "proactive". Networking in a planned and 
deliberate way is "proactive" networking. Otherwise it is "reactive" networking. Networking with actors with the intension to create strong ties requires a proactive behaviour (Kuss \& Griffiths, 2011). Most entrepreneurs are not aware that formal and informal networking contributes to the acquisition of entrepreneurial capabilities and the achievement of entrepreneurial success (Treece et al., 1997; Rothschild \& Darr, 2005; Tipu \& Arain, 2011; Bøllingtoft, 2012).

\section{- Entrepreneurial Capabilities}

Entrepreneurial capabilities are the innate and learned abilities that help budding and established entrepreneurs to identify, explore and exploit opportunities through new or existing business. Hall (1992) used capabilities, competencies and skills interchangeably to refer intangible resources that consist of the ability to adequately manage the resources needed to perform a task within an enterprise (Barba-Sanchez \& Atienza-Sahuquillo, 2010). Abdelgawad et al. (2013) define entrepreneurial capabilities as a firm's capacity to sense, select and shape opportunities, and synchronize their strategic moves and resources in pursuit of these opportunities. In entrepreneurship, capabilities develop as actors seek to deploy resources strategically. The two broad forms of capabilities (Winter, 2003) are dynamic capabilities and substantive (growth) capabilities. Dynamic capabilities are the abilities to reconfigure a firm's resources and routines in the manner envisioned and deemed appropriate by its principal decision-maker(s) (Zahra et al., 2006).

There are two main types of dynamic capabilities; (1) sensing - capability to identify new opportunities and (2) seizing - capability to exploit an opportunity through the mobilization of resources to amend and/or develop new capabilities. Eisenhardt and Martin (2000) assert that in larger firms, the creation of dynamic capabilities requires the development and refinement of routines for identification and exploitation of opportunities. Firms that continuously and proactively identify opportunity, and continuously regenerate their knowledge and capabilities perform better than the more conservative firms (Covin \& Miles, 1999). In smaller and less formalized firms, dynamic capabilities may be based on the skills and knowledge of an entrepreneur or entrepreneurial team. These dynamic capabilities are based on the entrepreneur and entrepreneurial team's perception of opportunities to productively change existing routines or resource configurations, their willingness to undertake such change, and their ability to implement these changes (Korr et al., 2007).

Substantive capabilities are the resources (e.g., knowledge and financial assets), organizational processes and the managerial decisions that are made with respect to a firm's resources and processes. It also implies the combinations of complementary resources and processes. A firm has substantive capabilities when it shows changes in size, market share, profitability and assets over time. Also, when the growth-creating processes are successfully repeated over time to form routines the firm is said to have substantive capabilities. (Teece et al.,1997). A process is effective if it can be repeated and routinized. Routines are repetitive, recognizable patterns of interdependent actions, carried out by multiple actors (Feldman \& Pentland, 2003).

Substantive capabilities enable a firm to compete in its market on a day-to-day basis, while dynamic capabilities extend, modify or create new substantive (growth) capabilities. New product development constitutes a substantive capability, whereas, a dynamic capability is the ability to build, direct and enhance the capability for new product development (Helfat \& Peteraf, 2003). Thus, dynamic capabilities are important in the development of substantive capabilities.

- Entrepreneurial Success

Entrepreneurial success is defined as positively affecting the lives of others and making a living through a well managed innovative product and/or service (Agbim \& Oriarewo, 2012). Entrepreneurial success is attributed to personal characteristics and managerial skills. The personal success factors of entrepreneurs are creativity and innovation, risk taking orientation, leadership, good human relations, a positive attitude, perseverance and 
commitment. Managerial success factors on the other hand, include planning, knowledge of competitors, mainly being market oriented, client service delivery, setting a high quality as priority, financial insight and management, knowledge and skills with regard to the business (Nieman et al., 2003).

Success is measured in terms of sales growth, income growth, employment trends and satisfaction (Hisrich, 2000). Success is also measured by the extent the business meets the desires and aspirations of interested stakeholders. However, entrepreneurial success is difficult to measure (Zahra et al., 2002). This is because new ventures are not obligated to disclose performance information and financial performance measures (e.g., ROI and ROA) have inherent challenges and are often unavailable (Chandler \& Hanks, 1993), and business owners are unwilling to share this information with outsiders (Dess \& Robinson, 1984). The use of the traditional measures is not appropriate because of the enormous and erratic growth rates or small starting capital (Walsh \& White, 1981).

Thus, researchers have advocated the use of objective and subjective measures in assessing entrepreneurial success. Objective success is computed by analyzing the figures in financial records; while subjective success is assessed more in terms of personal beliefs or views (Reijonen, 2008). Subjective measures are often self-report measures at the firm and/or individual levels of analysis (Haber \& Reichel, 2005). Success is not computed from stock market reports because entrepreneurial firms are often studied before going public (Eisenhardt \& Schoonhoven, 1990).

The methods adopted by researchers to overcome the difficulties associated with acquiring and using financial measures include: (1) asking respondents to state the importance and satisfaction with their relative firm on several performance measures (Gupta \& Govindarajan, 1984); (2) asking founders to compare the performance of their companies with their closest competitors (Sapienza et al., 1988). Relating EI to entrepreneurship, Baron (2000) opines that the ability to interact effectively with others is vital for success. Karimi et al. (2012) asserts that EI contributes to entrepreneurial success.

\section{Family Business or Entrepreneurship}

Family business or entrepreneurship is "a small, medium-sized, large or multinational enterprise established or bought over through a solo or family (two or more individuals related by blood or marriage) entrepreneurial efforts and operated based on a high level of trust, commitment, familiness, involvement and control by the owning family and a somewhat fused ownership, management and/or governance systems with the founder, descendant or external CEO directing the achievement of the developmental and trans-generational visions of the family business" (Agbim, 2018: 5).

\subsection{Previous Studies on EI and the Dimensions of Entrepreneurship Development}

Mortan et al. (2014) studied the contribution of the dimensions of EI (regulation and utilization of emotions) to entrepreneurial self-efficacy and intention. It was found that the two dimensions positively affect entrepreneurial self-efficacy and the later mediates the relation between EI and the intention to become an entrepreneur. Farahbod et al. (2013) found that there is an indirect relationship between EI and entrepreneurial intention. Hassan and Omar (2016) investigated the role of EI and entrepreneurial attitude in determining entrepreneurial intention among students. The result shows that EI is significantly related to entrepreneurial attitude and intention. Torres-Coronas et al. (2015) carried out a study to determine how trait EI supports proactive networking behaviour among entrepreneurs. The result shows that proactive networking is not related to EI. In a study to determine the impact of EI on entrepreneurial skills, Rajan (2015) found that EI influences entrepreneurial skills. Some researchers also allude to the fact that EI improves capabilities (Goleman, 1995; Khatoon, 2013). The result of the study conducted by Baron and Markman (2000) reveal that greater social abilities increase entrepreneurial success. Cross and Travaglione (2003) studied five Austrian entrepreneurs 
through in-depth interviews. The results suggest that entrepreneurs with greater overall EI achieve success in work and social environments. Danquah (2015) examined the effect of EI on financial performance (success). The result reveals that EI positively relates to financial performance.

\section{Research Methodology}

The study adopted mail questionnaire survey design. Nine Lebanese family-owned entrepreneurships in Nigeria (three each in Lagos, Port Harcourt and Kano States) were selected for the study on the basis of the population of Lebanese working in them. EI was assessed using the Emotional Competency Inventory (ECI) developed by Goleman (2001). The Cronbach's alpha test value for ECI is 0.84. Entrepreneurial intention was measured using two items: "I intend to start my own business in the near future" and "I intend to work hard at starting my own business." These items are based on Krueger et al.'s (2000) understanding of entrepreneurial intention. This scale has a Cronbach's alpha of 0.88 . The measures for entrepreneurial networking were adopted from the study of Torres-Coronas et al. (2015). Torres-Coronas et al. measured networking as strategic versus non-strategic and online versus offline. The entrepreneurial networking scale showed a Cronbach's alpha of 0.82. Entrepreneurial capabilities scale was adapted from the study conducted by Lv et al. (2011). The scale showed a Cronbach alpha test value of 0.72 . The questionnaire items for measuring entrepreneurial success were adapted from the work of McLaughlin (2012). The scale showed a Cronbach alpha test value of 0.76. All the item statements in the questionnaire were measured on a 7-point Likert scale that ranged from strongly agree (7) to strongly disagree (1).

A total of 155 questionnaire were mailed to the respondents through their Human Resource Managers (HRMs). Each questionnaire was accompanied by a self addressed and stamped envelope for the purpose of returning back the completed questionnaire. The researcher made reminder calls to the HRMs every Monday. At the end of six weeks 130 of the questionnaire were retrieved and useable. The study hypotheses were tested using the collected data. Pearson's correlation was used to test the hypotheses with the aid of SPSS (Version 21.0 for Windows) at $5 \%$ level of significance. The decision rule is to reject the null hypothesis if the p-value is less than or equal to $5 \%$. Otherwise do not reject.

\section{Results}

\section{Hypothesis one}

$\mathrm{H}_{01}$ : There is no significant relationship between EI and entrepreneurial intention.

$\mathrm{H}_{\mathrm{a} 1}$ : There is a significant relationship between EI and entrepreneurial intention.

Table 1: Correlation of EI and Entrepreneurial Intention

\begin{tabular}{llll}
\hline \multirow{2}{*}{ EI } & & EI & \multicolumn{1}{c}{$\begin{array}{c}\text { Entrepreneurial } \\
\text { Intention }\end{array}$} \\
\hline & Pearson Correlation & 1 & $.715^{* *}$ \\
\cline { 2 - 4 } & Sig. (2-tailed) & & .000 \\
\cline { 2 - 4 } & $\mathrm{N}$ & 130 & 130 \\
\hline Entrepreneurial Intention & Pearson Correlation & $.715^{* *}$ & 1 \\
\cline { 2 - 4 } & Sig. (2-tailed) & .000 & \\
\cline { 2 - 4 } & $\mathrm{N}$ & 130 & 130 \\
\hline
\end{tabular}

$$
\text { **sig. (2-tailed) at } .05
$$

Source: Author's computation, 2018 
The result of the Pearson correlation coefficient of the relationship between EI and entrepreneurial intention is presented in Table 1 . The coefficient suggests that the correlation is significant $(r=0.715, p=.000)$. Thus, $\mathrm{H}_{01}$ is rejected. It can be deduced that there is a significant relationship between EI and entrepreneurial intention.

Hypothesis two

$\mathrm{H}_{02}$ : EI is not significantly related to entrepreneurial networking.

$\mathrm{H}_{\mathrm{a} 2}$ : EI is significantly related to entrepreneurial networking.

Table 2: Correlation of EI and Entrepreneurial Networking

\begin{tabular}{llll}
\hline \multirow{2}{*}{ EI } & & EI & \multicolumn{1}{c}{$\begin{array}{c}\text { Entrepreneurial } \\
\text { Networking }\end{array}$} \\
\cline { 2 - 4 } & Pearson Correlation & 1 & $.853^{* *}$ \\
\cline { 2 - 4 } & Sig. (2-tailed) & 130 & .003 \\
\cline { 2 - 4 } & $\mathrm{N}$ & $.853^{* *}$ & 130 \\
\hline Entrepreneurial Networking & Pearson Correlation & .003 & \\
\cline { 2 - 4 } & Sig. (2-tailed) & 130 & 130 \\
\cline { 2 - 4 } & $\mathrm{N}$ & & \\
\hline
\end{tabular}

$$
\text { **sig. (2-tailed) at .05 }
$$

Source: Author's Computation, 2018

Table 2 depicts the Pearson correlation coefficient of the relationship between EI and entrepreneurial networking. The coefficient reveals that the relationship is significant $(\mathrm{r}=0.853, \mathrm{p}=.003)$. Hence, $\mathrm{H}_{02}$ is rejected. This suggests that EI is significantly related to entrepreneurial networking.

Hypothesis three

$\mathrm{H}_{03}$ : There is no significant relationship between EI and entrepreneurial capabilities.

$\mathrm{H}_{\mathrm{a} 3}$ : There is a significant relationship between EI and entrepreneurial capabilities.

Table 3: Correlation of EI and Entrepreneurial Capabilities

\begin{tabular}{llll}
\hline & & EI & \multicolumn{1}{c}{$\begin{array}{c}\text { Entrepreneurial } \\
\text { Capabilities }\end{array}$} \\
\hline \multirow{2}{*}{ EI } & Pearson Correlation & 1 & $.744^{* *}$ \\
\cline { 2 - 4 } & Sig. (2-tailed) & .001 \\
\cline { 2 - 4 } & $\mathrm{N}$ & 130 & 130 \\
\hline Entrepreneurial Capabilities & Pearson Correlation & $.744^{* *}$ & 1 \\
\cline { 2 - 4 } & Sig. (2-tailed) & .001 & \\
\cline { 2 - 4 } & $\mathrm{N}$ & 130 & 130 \\
\hline & $* *$ sig. (2-tailed) at .05 & \\
\hline
\end{tabular}

Source: Author's Computation, 2018

Table 3 shows the Pearson correlation coefficient of the relationship between EI and entrepreneurial capabilities. The coefficient implies that the relationship is significant $(r=0.744, p=.001)$. Based on this result, $\mathrm{H}_{03}$ is rejected. Thus, there is a significant relationship between EI and entrepreneurial capabilities. 
Hypothesis four

$\mathrm{H}_{04}$ : EI is not significantly related to entrepreneurial success.

$\mathrm{H}_{\mathrm{a} 4}$ : EI is significantly related to entrepreneurial success.

Table 4: Correlation of EI and Entrepreneurial Success

\begin{tabular}{llll}
\hline & & EI & \multicolumn{1}{c}{$\begin{array}{c}\text { Entrepreneurial } \\
\text { Success }\end{array}$} \\
\hline \multirow{2}{*}{ EI } & Pearson Correlation & 1 & $.964^{* *}$ \\
\cline { 2 - 4 } & Sig. (2-tailed) & & .000 \\
\cline { 2 - 4 } & $\mathrm{N}$ & 130 & 130 \\
\hline Entrepreneurial Success & Pearson Correlation & $.964^{* *}$ & 1 \\
\cline { 2 - 4 } & Sig. (2-tailed) & .000 & \\
\cline { 2 - 4 } & $\mathrm{N}$ & 130 & 130 \\
\hline
\end{tabular}

**sig. (2-tailed) at .05

Source: Author's Computation, 2018

Table 4 shows the Pearson correlation coefficient of the relationship between EI and entrepreneurial success. The coefficient reveals that the relationship is significant $(r=0.964, p=.000) . \mathrm{H}_{04}$ is therefore rejected. It can be deduced that EI is significantly related to entrepreneurial success.

\section{Discussion}

This study has shown that EI is related to entrepreneurial intention, entrepreneurial networking, entrepreneurial capabilities and entrepreneurial success. These results are somewhat similar to previous findings (Cross \& Travaglione, 2003; Farahbod et al., 2013; Mortan et al., 2014; Rajan, 2015; Danquah, 2015; Hassan \& Omar, 2016) except the study by Torres-Coronas et al. (2015). Torres-Coronas et al. found that proactive networking is not related to EI. The difference between the current study and that of Torres-Coronas et al. could be linked to the fact that while the current study focuses on immigrant entrepreneurs Torres-Coronas et al. looked at entrepreneurs in their home country. The current study contributes to the EI and entrepreneurship literature by examining how EI influences entrepreneurial intention, entrepreneurial networking, entrepreneurial capacities and entrepreneurial success among immigrant entrepreneurs. Lofstrom (2014) asserts that immigrants are widely perceived to be highly entrepreneurial, contributing to economic growth and innovation. However, they take to self-employment owing to the discrimination and challenges they face when seeking for job in the host country (Chrysostome, 2010; Omar, 2011; Ensign \& Robinson, 2011).

When immigrants resort to self-employment on account of inability to secure paid employment, they need financial resources to start-up and further develop their businesses. They need these financial resources to pay for expenses that are related to the advice of lawyers and accountants, procurement, lease, energy, taxes and unexpected lawsuits. Yet, they find it difficult to access financial resources from the formal financial institutions (Chrysostome and Arcand, 2009). This inability to access funds from formal financial institutions has the tendency to create stress in these immigrants. When the stress in these immigrants is regulated it facilitates the linking of trait EI with positive attitudes towards entrepreneurship and entrepreneurial intentions. Thus, immigrant entrepreneurs who have high EI are likely to develop high entrepreneurial intention and consequently motivate these immigrants to strive to overcome all challenges associated with starting a business to show high entrepreneurial behaviour. In addition, Khatoon (2013) asserts that EI improves an individual's social effectiveness in entrepreneurship. 
High entrepreneurial behaviour is still not enough to assure immigrant entrepreneurship development. This is because as noted by Chrysostome and Arcand (2009) the immigrants are poor. However, research has shown that higher EI will lead to better social network, which will in turn lead to better business relations (Khatoon, 2013). This implies that immigrant entrepreneurs need to be actively involved in entrepreneurial networking to access the resources they need. Ahmetoglu et al. (2011) opine that individuals that are high in EI are more likely to be highly creative and involved in innovative entrepreneurial activities and networks. This is because aside face-to-face networking, EI is increasingly becoming significant in social networking. Social networks are vital for new business start-up and development (Munkejord, 2017). Highly successful entrepreneurs are the ones who build strong relationships and effectively manage their networks (Bhattacharyya, 2010).

One of the reasons entrepreneurs network is to acquire entrepreneurial capabilities which Hall (1992) describe as intangible resources. Entrepreneurs also network to sense, select and shape opportunities, and choose their strategic moves (Abdelgawad et al. (2013). EI help to understand those individuals, who are able to innovate, discover, create and exploit opportunities (Pradhan \& Nath, 2012). The expected outcome of immigrant entrepreneurs' entrepreneurial intention, networking and capabilities are entrepreneurial success. Today, Lofstrom (2014) asserts that owing to the successes of self-employment and immigrant entrepreneurship (Kerr \& Lincoln, 2010; Fairlie \& Lofstrom, 2014) to the host countries, many countries are beginning to establish special visas and entry requirements so as to attract immigrant entrepreneurs (Lofstrom, 2014).

\section{Conclusion}

The results of this study have shown that EI influences the entrepreneurial intention, entrepreneurial networking, entrepreneurial capabilities and entrepreneurial success of immigrant entrepreneurs. Moreover, the host country where the immigrant entrepreneurships are established benefits in the form of job creation, infrastructural development, scholarship to indigent students, donations, improvement in the host country's innovativeness and increased revenue to the government. The study is limited in scope as only Lebanese family-owned businesses in the South West, South South and North West Nigeria were surveyed thus excluding the North Central, South East and North East geopolitical zones of Nigeria where some Lebanese family-owned businesses also exist. Further studies can be conducted in the other geopolitical zones or better still in other parts of the world to enhance the generalization of the results. The managerial implication of this study relates to the influence of EI on the dimensions of immigrant entrepreneurship development. This suggests exposing new immigrants and immigrant entrepreneurs to trainings and programs that will improve their emotional intelligence, entrepreneurial behaviour, capabilities, networking attitude and success mindset. The overall effect of these trainings and programs is the development of more immigrant entrepreneurships.

\section{References}

Aaltonen, S. \& Akola, E. (2014). Lack of trust -the main obstacle for immigrant entrepreneurship? Turku School of Economics, University of Turku. Retrieved from http://pyk2.aalto.fi/ncsb2012/Aaltonen.pdf on June 30, 2018.

Abdelgawad, S.G., et al. (2013). Strategic leadership and entrepreneurial capability for game change. Journal of Leadership \& Organizational Studies, 20(4), 394-407.

Adebayo, P. (2003). The Lebanese in Nigeria: The Lebanese and economy of Lagos,1890-1980. University of Ilorin (unpublished Ph.D thesis), Ilorin.

Adebayo, P. (n.d.).Transnational networks of the Lebanese-Nigerian Diaspora. Middle East Institute Viewpoints. Retrieved from www.mei.edu on July 2, 2018.

Agbim, K. C. \& Oriarewo, G. O. (2012). Spirituality as correlate of entrepreneurship development. Journal of Research in National Development, 10(3), 154-164. 
Agbim, K. C., Owutuamor, Z. B. \& Oriarewo, G. O. (2013). Entrepreneurship development and tacit knowledge: Exploring the link between entrepreneurial learning and individual know-how. Journal of Business Studies Quarterly, 5(2), 112-129.

Agbim, K. C. (2018). Business network effect on the institutionalization of family businesses in South Eastern Nigeria. Open Journal of Economics and Commerce, 1(1), 1-10.

Ahmetoglu, G., Leutner, F., \& Chamorro, T. (2011). EQ-nomics: Understanding the relationship between individual differences in trait emotional intelligence and entrepreneurship. Personality and Individual Differences, 51, 1028-1033.

Ajzen, I. (1991). The theory of planned behavior. Organizational Behaviour and Human Decision processes, 50, 179-211.

Aslan, Ş. \& Erkuş, A. (2008). Measurement of emotional intelligence: Validity and reliability studies of two scales. World Applied Sciences Journal, 430-438.

Bagwell, S. (2008). Transnational family networks and ethnic minority business development. The case of Vietnamese nail-shops in the UK. International Journal of Entrepreneurial Behaviour \& Research, 14, 377-394.

Barba-sanchez, V. \& Atienza-Sahuquillo, C. (2010). Integration of the environment in managerial strategy: Application of the resource-based theory of competitive advantage, dynamic capabilities. African Journal of Business Management, 4(6), 1155-1165.

Bar-On, R. (1997). The emotional quotient inventory (EQ-i): Technical manual. Toronto: Multi-Health Systems.

Baron, R. A. \& Markman, G. D. (2000). Beyond social capital: How social skills can enhance entrepreneurs' success. Academy of Management Executive, 14(1), 106-131.

Baron, R. A. (2000). Counterfactual thinning and venture formation: The potential effects of thinking about "what might have been." Journal of Business Venturing, 14(1), 106-116.

Bhattacharyya, A. (2010). The networking entrepreneur. The Journal of Entrepreneurship, 19(2), 209-221.

Bird, B. J. (1989). Entrepreneurial behavior. Glenview: Scott Foreman.

Bøllingtoft, A. (2012). The bottom-up business incubator: Leverage to networking and cooperation practices in a self-generated, entrepreneurial-enabled environment. Technovation, 32, 304-315.

Boyatzis, R., Goleman, D. \& Rhee, K. (1998). Clustering competence in emotional intelligence: Insights from the emotional competence inventory (ECI).

Cabanac, M. (2002). What Is Emotion? Behavioural Processes, 60, 69-84.

Caruso, D. R., Mayer, J. D. \& Salovey, P. (2002). Relation of an ability measure of emotional intelligence to personality. Journal of Personality Assessment, 306-320.

Chandler, G. \& Hanks, S. (1993). Measuring the performance of emerging businesses: A validation study. Journal of Business Venturing, 8, 391-408.

Cheuk, B. (2007). Social networking analysis: Its application to facilitate knowledge transfer. Business Information Review, 24, 170-176.

Chrysostome, E. \& Arcand, S. (2009). Survival of necessity immigrant entrepreneurs: An exploratory study. Journal of Comparative International Management, 12(2), 3-29.

Chrysostome, E. \& Lin, X. (2010). Immigrant entrepreneurship: Scrutinizing a promising type of business venture. Thunderbird International Business Review, 52(2), 77-82.

Chrysostome, E. (2010). The success factors of necessity immigrant entrepreneurs: In search of a model. Thunderbird International Business Review, 52(2), 137-152.

Collins, J. \& Low, A. (2010). Asian female immigrant entrepreneurs in small and medium-sized businesses in 
Australia. Entrepreneurship and Regional Development 22(1), 97-111.

Correa, T., Hinsley, W. A. \& Gil de Zúñiga, H. (2010). Who interacts on the Web? The intersection of users' personality and social media use. Computers in Human Behaviour, 26(2), 247-253.

Cote, S., Lopes, P. N., Salovey, P. \& Miners, C. T. H. (2010). Emotional intelligence and leadership emergence in small groups. The Leadership Quarterly, 21, 496-508.

Covin, J. G. \& Miles, M. P. (1999). Corporate entrepreneurship and the pursuit of competitive advantage. Entrepreneurship Theory Practice, 23(3), 47-64.

Cross, B. \& Travaglione, A. (2003). The untold story: Is the entrepreneur of the 21 st century defined by emotional intelligence? The International Journal of Organizational Analysis, 11(3), 221-228.

Dalhammar, T. (2004). Voices of entrepreneurship and small business- immigrant enterprises in Kista. Retrieved from http://www.diva-portal.org/smash/get/diva2:7559/FULLTEXT01.pdf on February 24, 2018.

Danquah, E. (2015). The effect of emotional intelligence on the financial performance of commercial banks in Ghana: The mediation role of relationship marketing, service quality, customer satisfaction. British Journal of Marketing Studies, 3(2), 8-25.

Dess, G. G. \& Robinson, R. B. (1984). Measuring organizational performance in the absence of objective measures: The case of the privately held firm and conglomerate business unit. Strategic Management Journal, 5, 297-312.

Eisenhardt, K. M. \& Martin, J. A. (2000). Dynamic capabilities: What are they? Strategic Management Journal, 21(10/11),1105-1121.

Eisenhardt, K. M. \& Schoonhoven, K. (1990). Organizational growth: Linking founding team strategy, environment, and growth among U.S. semiconductor ventures, 1978-1988. Administrative Science Quarterly, 35, 504-529.

Ensign, P. C. \& Robinson, N. P. (2011). Entrepreneurs because they are immigrants, or immigrants because they are entrepreneurs? A critical examination of the relationship between the newcomers and the establishment. Journal of Entrepreneurship, 20, 33-53.

Fairlie, R. W. \& Lofstrom, M. (2014). Immigration and entrepreneurship, In B. Chiswick \& P. Miller (Eds.), Handbook on the Economics of International Immigration. Amsterdam: Elsevier.

Fakhreldin, H. \& Hattab, H. (2015). The effect of emotional intelligence on the new venture creation of necessity and opportunity-driven Egyptian entrepreneurs. Paper presented at The 2015 International Academic Research Conference, London, December, 7-9.

Farahbod, F., Azadehdel, M., Mofidi, M. K., Shahabi, S., khoshamooz1, H., Pazhouh, L. D., Ghorbaninejad, N. \& Shadkam, F. (2013). The relationship between trait emotional intelligence and entrepreneurship attitudes and intentions. Journal of Public Administration and Policy, 5(3), 79-85. doi: 10.5897/JPAPR2013.0242

Feldman, M. S. \& Pentland, B. T. (2003). Reconceptualizing organizational routines as a source of flexibility and change. Administrative Science Quarterly, 48, 94-118.

Forret, M. L. \& Dougherty, T. W. (2001). Correlates of networking behaviour for managerial and professional employees. Group, Organization and Management, 26(3), 283-311.

Gardner, H. (1983). Frames of mind: A theory of multiple intelligences. New York: Basic Books.

Goleman, D. (1995). Emotional intelligence. New York: Bantam Books.

Goleman, D. (2001). Emotional intelligence: Issues in paradigm building, In C. C. Goleman, The Emotionally Intelligence Workplace. San Francisco: Jossey-Bass.

Greenberg, J. \& Baron, R. A. (2008). Behaviour in organizations. 
Gupta, A. K. \& Govindarajan, V. (1984). Business unit strategy, managerial characteristics, and business unit effectiveness at strategy implementation. Academy of Management Journal, 27, 25-41.

Haber, S. \& Reichel, A. (2005). Identifying performance measures of small ventures: The case of the tourism industry. Journal of Small Business Management, 43(3), 257-286.

Hall, R. (1992). The strategic analysis of intangible resources. Strategic Management Journal, 13, 135-144.

Hassan, R. A. \& Omar, S. N. B. (2016). The effect of emotional intelligence and entrepreneurial attitude on entrepreneurial intention. Kuwait Chapter of Arabian Journal of Business and Management Review, 5(12), $1-10$.

Helfat, C. E. \& Peteraf, M. A. (2003). The dynamic resource-based view: Capability lifecycles. Strategic Management Journal, 24(10), 997-1010.

Hisrich, R. D. (2000). Entrepreneurial dimensions: The relationship of individual, venture, and environmental factors to success. Entrepreneurship Theory and Practice, 24(4), 79-80.

Joseph, S. (2006). Civic myths, citizenship and gender in Lebanon, In S. Joseph (Ed.), Gender in the Middle East (p. 116). Syracuse: Syracuse University Press.

Kahn. S., La Mattina, G., MacGarvie, M. \& Ginther, D. K. (2013). "Hobos", "stars" and immigrant entrepreneurship. Retrieved from http://people.bu.edu/skahn/entrepreneurship_kahn\%20et\%20al.pdf on January 15, 2018.

Karimi, P., Kloshani, M. \& Bakhshizadeh, A. (2012). A comparative study on emotional intelligence and cognitive between successful and unsuccessful entrepreneurs. Management Science Letters, 2(6), 2071-2076.

Kariv, D., Menzies, T. V., Brenner, G. A., et al. (2009). Transnational networking and business performance: Ethnic entrepreneurs in Canada. Entrepreneurship and Regional Development, 21, 239-264.

Kerr, W. R. \& Lincoln, W. F. (2010). The supply side of innovation: H-1B visa reforms and U.S. ethnic invention. Journal of Labour Economics 28(3), 473-508.

Khatoon, N. (2013). The impact of emotional intelligence on the growth of entrepreneurship. International Journal of Business Management \& Research, 3(3), 1-8.

Korr, Y. Y., Mahoney, J. T. \& Michaels, S. C. (2007). Resources, capabilities and entrepreneurial perceptions. Journal of Management Studies, 44(7), 1178-1212.

Krueger, N. F. J., Reilly, M. D. \& Carsrud, A. L. (2000). Competing models of entrepreneurial intention. Journal of Business Venturing, 15, 411-32.

Kuss, D. J. \& Griffiths, M. D. (2011). Online social networking and addiction: A review of the psychological literature. International Journal of Environmental Research and Public Health, 8, 3528-3552.

Leblang, D., Fitzgerald, J. \& Teets, J. (2006). Defying the law of gravity: The political economy of international migration. Department of Political Science, University of Colorado, Boulder. Retrieved from http://socsci.colorado.edu/-leblang/Research_files/Defying.pdf. on November 6, 2017.

Lofstrom, M. (2014). Immigrants and entrepreneurship. Public Policy Institute of California, USA, and IZA, Germany. doi: 10.15185/izawol.85

Lv, R. W., Lai, C. \& Liu, J. (2015). Entrepreneurial capability scale and new venture performance: The moderating role of entrepreneurship education. National Social Science Foundation of China.

Mayer, J. D. \& Salovey, P. (1997). What is emotional intelligence? In P. Salovey \& D. Sluyter (Eds.), Emotional development and emotional intelligence: Implications for educators (pp. 3-31). New York: Basic Books.

Mayer, J. D., Salovey, P. \& Caruso, D. R. (2002). MSCEIT user's manual. Toronto: Multi-Health Systems.

Mayer, J. D., Salovey, P. \& Caruso, D. R. (2004). Target articles: Emotional intelligence theory, findings and 
implications. Psychological Inquiry, 15(3), 197-215.

Mayer, J. D., Salovey, P., Caruso, D. R. \& Sitarenios, G. (2001). Emotional intelligence as a standard intelligence.

McLaughlin, E. B. (2012). An emotional business: The role of emotional intelligence in entrepreneurial success. University of North Texas (unpublished Ph.D thesis), North Texas.

Mortan, R. A., Ripoll, P., Carvalho, C. \& Bernal, M. C. (2014). Effects of emotional intelligence on entrepreneurial intention and self-efficacy. Journal of Work and Organizational Psychology, 30, 97-104.

Munkejord, M. C. (2017). Local and transnational networking among female immigrant entrepreneurs in peripheral rural contexts: Perspectives on Russians in Finnmark, Norway. European Urban and Regional Studies, 24(1), 7-20. doi: 10.1177/0969776415587122

Muscanell, N. \& Guadagno, R. (2012). Make new friends or keep the old: Gender and personality differences in social networking use. Computers in Human Behaviour, 28, 107-112.

Neiman, G., Hough, H. \& Neiwenhuizen, C. (Eds.) (2003). Entrepreneurship: A South African perspective. Pretoria: Van Schaik.

Nikolaou, I. \& Tsaousis, I. (2002). Emotional intelligence in the workplace: Exploring its effects on occupational stress and organizational commitment. International Journal of Organizational Analysis, 10, 327- 342.

O'Donnell, A. (2004). The nature of networking in small firms. Qualitative Market Research: An International Journal, 7(3), 206-217.

Oliveira, C. R. (2008). Factors that encourage or discourage immigrant's entrepreneurial behaviour. Proceedings of the European network on Ethnic Minority Business Workshop, Brussels, Belgium, March 5. Retrieved from http//:www.ec.europa.eu/enterprise/newsroom/cf/_getdocument.cfm?doc_id=3311 on April 16, 2018.

Omar, H. (2011). Arab American entrepreneurs in San Antonio, Texas: Motivation for entry into self-employment. Education, Business and Society: Contemporary Middle Eastern Issues, 4(1), 33-42.

Paoloni, M., Valeri, M \& Paoloni, P. (2017). Immigrant women's entrepreneurship: Is there a development model in Italy? African Journal of Business Management, 11(15), 357-366. doi: 10.5897/AJBM2017.8342

Petrides, K. V. (2001). A psychometric investigation into the construct of emotional intelligence. University College London (unpublished Ph.D thesis), London.

Pistrui, D., Fahed-Sreih, J., Huang, W. \& Welsch, H. (2008). Entrepreneurial led family business development in post-war Lebanon. USASBE 2008 Proceedings.

Plamondon, B. (2004). Economics of Middle East and Africa. Global Insight Report, Lebanon.

Pradhan R. K. \& Nath P., (2012), Perception of Entrepreneurial Orientation and Emotional Intelligence: A Study on India's Future Techno-Managers. Global Business Review, 13(1), 89-108.

Rajan, M. P. (2015). Impact of emotional intelligence on entrepreneurial skills among engineering students. Shanlax International Journal of Management, 2(4), 40-45.

Reijonen, H. (2008). Understanding the small business owner: What they really aim at and how this relates to firm performance. Management Research News, 31(8), 616-629.

Rhee, K. S. \& White, R. J. (2007). The emotional intelligence of entrepreneur. Journal of Small Business and Entrepreneurship, 20, 409-426.

Rothschild, L. \& Darr, A. (2005). Technological incubators and the social construction of innovation networks: An Israeli case. Technovation, 25(1), 59-67.

Salovey, P. \& Mayer, J. D. (1990). Emotional intelligence. Imagination, Cognition and Personality, 9(3), $185-211$.

Sapienza, H. J., Smith, K. G. \& Gannon, M. J. (1988). Using subjective evaluations of performance in small 
business research. American Journal of Small Business, 13, 45-53.

Siqueira, A. C. O. (2007). Entrepreneurship and ethnicity: The role of human capital and family social capital. Journal of Developmental Entrepreneurship, 12(1), 31-46.

Slavnic, Z. (2004). Immigrant and small business research in Sweden: An overview. Themes on Migration and Ethnic Studies.

Slotte-Kock, S. \& Coviello, N. (2010). Entrepreneurship research on network processes: A review and ways forward. Entrepreneurship Theory and Practice, 34, 31-57.

Teece, D. J., Pisano, G. \& Shuen, A. (1997). Dynamic capabilities and strategic management. Strategic Management Journal, 18, 509-533.

Tengeh, R. K. \& Nkem, L. (2017). Sustaining immigrant entrepreneurship in South Africa: The role of informal financial associations. $\quad$ Sustainability, $\quad 9, \quad 1396 . \quad$ doi:10.3390/su9081396 www.mdpi.com/journal/sustainability

Tengeh, R.K., Ballard, H. \& Slabbert, A. (2011). A framework for acquiring the resources vital for the start-up of a business in South Africa: An African immigrant's perspective. European Journal of Social Science, 23, 262-381.

Tipu, S. \& Arain, F. (2011). Managing success factors in entrepreneurial ventures: A behavioural approach. International Journal of Entrepreneurial Behaviour and Research, 17(5), 534-560.

Torres-Coronas, T., Vidal-Blasco, M. \& Sánchez, J. D. (2015). The role of emotional intelligence in entrepreneurial networking. Journal of Entrepreneurship: Research \& Practice, 1-10. doi: $10.5171 / 2015.443841$

Vinogradov, E. \& Isaksen, E. (2008). Survival of new firms owned by natives and immigrants in Norway. Journal of Developmental Entrepreneurship, 13(1), 21-38.

Walsh, J. A. \& White, J. F. (1981). Small business ratio analysis: A cautionary note to consultants. Journal of Small Business Management, 3, 20-23.

Williams, C.C. (2008). The motives of off-the-books entrepreneurs: Necessity- or opportunity-driven? International Entrepreneurial Management Journal, 5, 203-217.

Winter, S. G. (2003). Understanding dynamic capabilities. Strategic Management Journal, 24, 991-995.

Wolff, H. \& Kim, S. (2012). The relationship between networking behaviours and the Big Five personality dimensions. Career Development International, 17(1), 43-66.

Wong, C. S. \& Law, K.S. (2002). Development of an emotional intelligence instrument and an investigation of its relationship with leader and follower performance and attitudes. The Leadership Quarterly, 13, 243-274.

Wong, C. S., Wong, P. M. \& Law, K. S. (2007). Evidence of practical utility of Wong's emotional intelligence scale in Hong Kong and Mainland China. Asia Pacific Journal of Management, 43-60.

Zahra, S. A., Neubaum, D. O. \& El-Hagrassey, G. M. (2002). Competitive analysis and new venture performance: Understanding the impact of strategic uncertainty and venture origin. Entrepreneurship Theory and Practice, 2-27.

Zahra, S. A., Sapienza, H. J. \& Davidsson, P. (2006). Entrepreneurship and dynamic capabilities: A review, model and research agenda. Journal of Management Studies, 43(4), 917-955.

Zampetakis, L. A., Kafetsios, K., Bouranta, N., Dewett, T. \& Moustakis, V. S. (2009). On the relationship between emotional intelligence and entrepreneurial attitudes and intentions. International Journal of Entrepreneurial Behaviour \& Research, 15(6), 595-618. doi:10.1108/13552550910995452

Zeidner, M., Matthews, G. \& Roberts, R. D. (2009). What we know about emotional intelligence: How it affects 
learning, work, relationships, and our mental health. Cambridge, MA: MIT Press.

\section{Copyrights}

Copyright for this article is retained by the author(s), with first publication rights granted to the journal.

This is an open-access article distributed under the terms and conditions of the Creative Commons Attribution license (http://creativecommons.org/licenses/by/4.0/). 